\title{
PERANCANGAN KNOWLEDGE MANAGEMENT SYSTEM PADA KANTOR DINAS PENDIDIKAN PEMDA OGAN ILIR
}

\author{
Helda Yudiastuti ${ }^{1}$, Irwansyah ${ }^{2}$ \\ Dosen Universitas Bina Darma ${ }^{1,2}$ \\ Jalan Jenderal Ahmad Yani No.3 Palembang \\ Sur-el : helda.yudiastuti@binadarma.ac.id ${ }^{1}$, irwansyah@binadarma.ac.id ${ }^{2}$
}

\begin{abstract}
Local government education offices Ogan Ilir is the government agency that is engaged in education. Local government education offices Ogan Ilir Inventory goods are now using Information Systems, but has not used a special program to summarize all the information. Given the high level of knowledge of data loss due to mutation and retired employees, the education office there is no one system that can organize, collect, document and knowledge transfer data into information. This situation raises awareness of the importance of the application of process knowledge system (Knowledge Management Sytem). Expected to facilitate the Education Office in processing the inventory of goods, knowledge-coordinated and well-organized. Based on the description above, the authors conducted a study with the title "Designing Knowledge Management Systems In Local Government Education Office Ogan Ilir'”.
\end{abstract}

Keywords: Knowladge Management System, Sub-Division of Human Resources

\begin{abstract}
Abstrak : Kantor Dinas Pendidikan PEMDA Ogan Ilir adalah instansi pemerintah yang bergerak dalam bidang pendidikan. Kantor Dinas Pendidikan PEMDA Ogan Ilir Inventaris barangnmya saat ini sudah menggunakan Sistem Informasi, tetapi belum menggunakan program khusus untuk merangkum semua informasi. Mengingat tingginya hilangnya data pengetahuan karena mutasi dan pensiun pegawai, kantor dinas pendidikan belum ada suatu system yang dapat mengatur, mengumpulkan, mendokumentasikan dan mentransfer data pengetahuan menjadi informasi. Keadaan ini menimbulkan kesadaran bahwa pentingnya suatu penerapan system pengolaan pengetahuan (Knowledge Management Sytem). Diharapkan dapat mempermudah Kantor Dinas Pendidikan dalam mengolah Inventaris barang sehingga pengetahuan tersebut terkoordinir dan terorganisir dengan baik. Berdasarkan uraian diatas penulis melakukan penelitian dengan judul " Perancangan Knowledge Management System Pada Kantor Dinas Pendidikan Pemda Ogan Ilir”.
\end{abstract}

Keywords: Knowladge Management System, Sub Bagian Kepegawaian

\section{PENDAHULUAN}

Knowledge Management System (KMS) merupakan suatu sistem komputer yang akan mengorganisir pengetahuan yang terdapat dalam organisasi atau perusahaan. Fungsi utama struktur knowledge management dari sebuah organisasi adalah menciptakan (creation), memetakan, mendistribusikan pengetahuan (transfer knowledge). ( Nawawi, 2012).
Kantor Dinas Pendidikan PEMDA OI (Pemerintah Daerah Ogan Ilir) memiliki sebuah sistem inventaris barang. Sistem inventaris barang ini sangat berperan penting bagi kantor dinas pendidikan karena sistem ini dapat menampilkan pencatatan dan pendaftaran barang-barang milik kantor. Tetapi Saat ini, sistem inventaris barang ini hanya dapat menyajikan informasi tentang barang itu saja. Sehingga kantor dinas belum dapat menyebarkan 
atau berbagi informasi dengan mudah dan cepat. Inventaris barang kantor dinas pendidikan adalah aset yang dimiliki oleh kantor dinas tersebut, dimana setiap tahunnya mengalami perubahan baik dalam jumlah maupun jenis barangnya. Setiap akhir tahun kantor dinas merangkum semua data atau informasi tentang aset kantor dinas pendidikan dalam bentuk laporan inventaris per tahun yang masih dibuat dalam bentuk dokumen-dokumen yang membuat para pegawai susah dalam pencarian, dan menyebarkan informasi. Sehingga dengan masalah tersebut pengetahuan kantor dinas pendidikan tentang inventaris belum terorganisir dengan baik. Selain itu perpindahan pegawai dapat menyebabkan pengetahuan tersebut hilang, dan pegawai baru memerlukan waktu yang banyak untuk mencari, memperoleh, menyebarkan dan berbagi pengetahuan atau informasi yang berguna bagi mereka.

Dengan masalah yang dihadapi oleh kantor dinas pendidikan pasti akan mengganggu kinerja para pegawai tersebut, yang biasanya tidak teraturnya keorganisasian sebuah inventaris kantor dikarenakan tidak adanya sebuah sistem pengetahuan dalam inventaris kantor dinas pendidikan. Maka kantor dinas pendidikan harus diimbangi dengan pemeliharaan atau mengembangankan pola pikir dengan sistem yang dapat mempermudah mereka dalam memperoleh informasi.

\section{METODOLOGI PENELITIAN}

\subsection{Metode Pengembangan Perangkat Lunak}

Metode pengembangan perangkat lunak yang digunakan dalam penelitian ini adalah model prototipe. Menurut Pressman (2002) prototyping paradigma dimulai dengan pengumpulan kebutuhan. Pengembang dan pelanggan bertemu dan mendefinisikan obyektif keseluruhan dari perangkat lunak, mengidentifikasi segala kebutuhan yang diketahui, dan area garis besar dimana definisi lebih jauh merupakan keharusan, kemudian dilakukan perancangan kilat. Perancangan kilat berfokus pada penyajian dari aspek-aspek perangkat lunak tersebut yang akan nampak bagi pelanggan/pemakai. Perancangan kilat membawa kepada konstruksi sebuah prototipe. Prototipe tersebut dievaluasi oleh pelanggan/pemakai dan dipakai untuk menyaring kebutuhan pengembangan perangkat lunak. Iterasi terjadi pada saat yang sama memungkinkan pengembang untuk secara lebih baik memahami apa yang harus dilakukannya. Secara ideal prototipe berfungsi sebagai sebuah mekanisme untuk mengidentifikasi kebutuhan perangkat lunak.

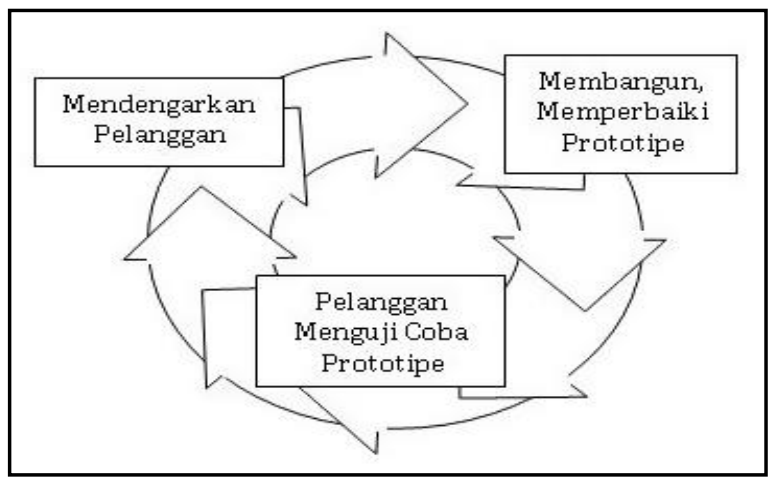

Gambar 1. Prototyping Paradigma 
Basit (2010) menjelaskan bahwa tahapantahapan dari model prototipe adalah sebagai berikut :

1. Pengumpulan Kebutuhan

Pelanggan dan pengembang bersamasama mendefinisikan format seluruh perangkat lunak, mengidentifikasikan semua kebutuhan, dan garis besar sistem yang akan dibuat.

2. Membangun Prototyping

Membangun prototyping dengan membuat perancangan sementara yang berfokus pada penyajian kepada pelanggan.

3. Evaluasi Prototyping

Evaluasi ini dilakukan oleh pelanggan apakah prototyping yang sudah dibangun sudah sesuai dengan keinginan pelanggan. Jika sudah sesuai maka langkah 4 akan diambil. Jika tidak prototyping akan direvisi dengan mengulang langkah 1, 2, dan 3 .

4. Mengkodekan Sistem

Dalam tahap ini prototyping yang sudah disepakati diterjemahkan ke dalam bahasa pemrograman yang sesuai.

5. Menguji Sistem

Setelah sistem sudah menjadi suatu perangkat lunak yang siap pakai, maka sistem harus di uji coba terlebih dahulu sebelum digunakan.

6. Evaluasi Sistem

Pelanggan mengevaluasi apakah sistem yang sudah jadi telah sesuai dengan yang diharapkan. Jika sesuai maka langkah 7 dilakukan. Tetapi jika tidak sesuai, ulangi langkah 4 dan 5 .
7. Menggunakan Sistem

Perangkat lunak yang telah diuji dan diterima pelanggan, selanjutnya siap untuk digunakan.

\subsection{Knowledge Management}

Menurut Nawawi, (2012), menjelaskan yang terdapat dibuku yang berjudul Knowledge Management (Teori Dan Aplikasi dalam mewujudkan daya saing organisasi bisnis dan publik), Knowledge Management adalah suatu pendekatan proses yang sistematis untuk mengelola aset intelektual dan informasi lain sehingga memberikan keunggulan bersaing bagi perusahaan.

\subsection{Knowledge Management System}

Menurut Tobing (2007), komponen utama dari knowledge management adalah people, process, dan technology. Masing-masing dari komponen ini akan saling terkait satu sama lain serta saling terintegrasi membentuk suatu landasan yang kuat untuk knowledge management. Lebih lanjut, menurut Tobing (2007), untuk mengatur dan mengelola knowledge yang terdapat pada organisasi dapat dimulai dengan mengelompokkan dan mengategorikan masalah yang ditemui di dalam organisasi. Hal ini dilakukan untuk mengidentifikasi kegiatan-kegiatan yang dianggap sebagai proses inti knowledge management yang terkait antara satu dengan yang lainnya.

\section{Komponen-komponen}

Knowledge

Management. Jika ditinjau lebih lanjut, Maka knowledge terbagi atas dua, yaitu : 


\section{Explicit Knowledge}

Knowledge yang dapat atau sudah dikodifikasikan dalam bentuk dokumen atau berbentuk wujud lainnya, sehingga dapat mudah ditransfer dan didistibusikan dengan menggunakan berbagai media. Ekplicit Knowledge dapat berubah formula, kaset, CD video dan audio, spesifikasi produk atau manual.

\section{Tacit Knowledge}

Tacit Knowledge merupakan knowledge yang diam dalam benak manusia dalam bentuk intuisi judgemen, skill, nilai (value) dan (belief) yang sangat sulit diformulasikan dan di-share dengan orang lain.

Perangkat teknologi informasi yang ada di organisasi melalui empat cara konversi diantaranya :

a. Sosialisasi, Proses sosialisasi antar sumber daya manusia (SDM) di organisasi salah satunya dilakukan melalui pertemuan tatap muka (rapat, diskusi, dan pertemuan bulanan). Melalui pertemuan tatap muka ini, SDM dapat saling berbagi knowledge dan pengalaman yang dimilikinya sehingga tercipta knowledge baru bagi mereka. Rapat dan diskusi yang dilakukan secara berkala harus notulen rapat. Notulen rapat ini kemudian menjadi bentuk eksplisit dari knowledge.

b. Eksternalisasi, Sistem Knowledge Management akan sangat membantu proses eksternalisasi ini, yaitu proses untuk mengartikulasi tacit knowledge menjadi suatu konsep yang jelas. Dukungan terhadap proses ekternalisasi ini dapat diberikan dengan mendokumentasikan notulen rapat ke dalam bentuk elektronik, untuk kemudian dapat dipublikasikan kepada mereka yang berkepentingan. Hasil dari diskusi tersebut didokumentasikan dan disimpan dalam suatu repository serta dapat dipublikasikan melalui sistem informasi yang ada di organisasi.

c. Kombinasi. Proses konversi knowledge melalui kombinasi adalah mengombinasikan berbagai explicit knowledge yang berbeda untuk disusun ke dalam sistem knowledge management, media untuk proses ini dapat melalui intranet, database organisasi dan internet untuk memperoleh sumber eksternal.

d. Internalisasi. Semua dokumen data, informasi dan knowledge yang sudah didokumentasikan dapat dibaca oleh orang lain. Pada proses inilah terjadi peningkatan knowledge sumber daya manusia. pemicu proses ini adalah penerapan pendidikan dan pelatihan para karyawan.

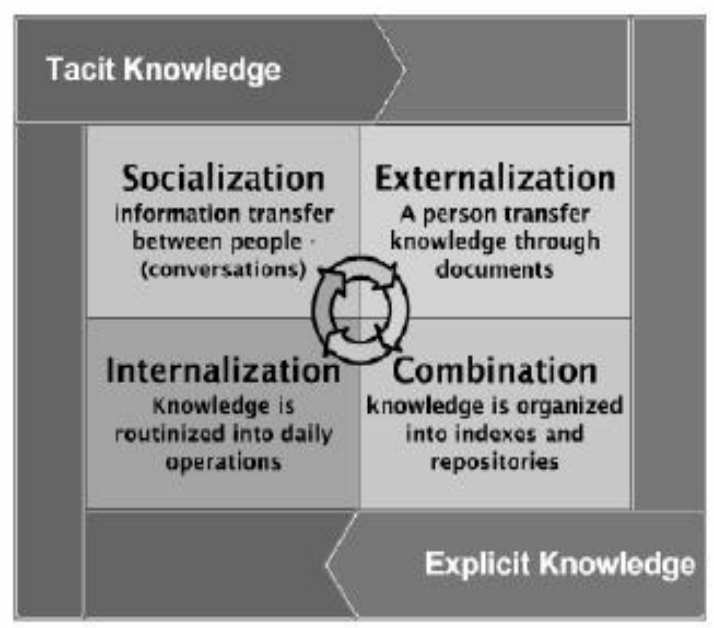

Gambar 2. Model SECI Penyebaran Empat Cara Konversi Pengetahuan.

\subsection{Sistem Informasi.}

Sistem informasi sendiri telah dikemukakan oleh beberapa penulis, Menurut Yakub (2012) "Sistem adalah suatu jaringan 
kerja dari prosedur-prosedur yang saling berhubungan, terkumpul bersama-sama untuk melakukan suatu kegiatan atau untuk tujuan tertentu". Selanjutnya Sutabri (2012) menyatakan: "Sistem adalah suatu kumpulan atau himpunan dari unsur, komponen, atau variabel yang terorganisasi, saling berinteraksi, saling tergantung satu sama lain dan terpadu". Sutabri (2012) menjelaskan tentang karakteristikdari sistem adalah:

a. Komponen Sistem (Components) Suatu sistem terdiri dari sejumlah komponen yang saling berinteraksi, yang bekerja sama membentuk satu kesatuan. Komponenkomponen sistem tersebut dapat berupa suatu bentuk subsistem.

b. b.Batasan Sistem (Boundary) Ruang lingkup sistem merupakan daerah yang membatasi antara sistem dengan sistem lainnya atau sistem dengan lingkungan luarnya. Batasan sistem ini memungkinkan suatu sistem dipandang sebagai satu kesatuan yang tidak dapat dipisah-pisahkan.

c. Lingkungan Luar Sistem (Environtment) Lingkungan luar sistem adalah bentuk apapun yang ada di luar ruang lingkup atau batasan sistem yang mempengaruhi operasi sistem tersebut.

d. Penghubung Sistem (Interface) Penghubung sistem atau interface adalah media yang menghubungkan sistem dengan subsistem yang lain.

e. Masukan Sistem (Input) Energi yang dimasukkan ke dalam sistem disebut masukan sistem, yang dapat berupa pemeliharaan (maintenance input) dan sinyal (signal input). f. Keluaran Sistem (Output) Keluaran ini merupakan masukan bagi subsistem yang lain.

\subsection{PHP (Personal Hypertext Preprocessor)}

Janner Simarmata (2006) menyatakan bahwa, "PHP (Personal Hypertext Preprocessor) adalah bahasa (scripting language) yang dirancang secara khusus untuk penggunaan pada web” . PHP (Personal Hypertext Preprocessor) merupakan bahasa pemrograman web yang bersifat open source (gratis). Bahasa PHP (Personal Hypertext Preprocessor) dapat bekerjasama dengan HTML dan sepenuhnya dijalankan pada web server".

\subsection{MySQL}

Mohamad Sukarno (2006) menyatakan bahwa, "MySQL merupakan perangkat lunak untuk sistem manajemen database (Database Management System) yang memiliki kemampuan menampung kapasitas yang sangat besar dan sifatnya open source" .

\subsection{Data Flow Diagram (DFD)}

Pressman (2002) menyatakan bahwa, “ Data Flow Diagram (DFD) adalah sebuah teknik grafis yang menggambarkan aliran informasi dan transformasi yang diaplikasikan pada saat data bergerak dari input menjadi output" .

Data Flow Diagram (DFD) adalah alat pembuatan model yang memungkinkan profesional sistem untuk menggambarkan sistem 
sebagai suatu jaringan proses fungsional yang dihubungkan satu sama lain dengan alur data, baik secara manual maupun komputerisasi. DFD merupakan salah satu alat pembuatan model yang sering digunakan, khususnya bila fungsifungsi sistem merupakan bagian yang lebih penting dan kompleks daripada data yang dimanipulasi oleh sistem. Dengan kata lain, DFD adalah alat pembuatan model yang memberikan penekanan hanya pada fungsi system.

\section{HASIL DAN PEMBAHASAN}

\subsection{Analisis}

Sistem inventaris pada kantor dinas merupakan sistem yang menyediakan informasi tentang data inventaris barang yang dimiliki oleh kantor dinas, seperti inventaris tanah, inventaris alat tulis kantor dan inventaris gedung dan bangunan. Inventaris tanah ditangani oleh bagian diskulpora, inventaris alat tulis kantor ditangani oleh bagian umum dan inventaris gedung dan bangunan ditangani oleh bagian bangunan.

Saat ini sistem inventaris yang baik secara terorganisir belum ada, sehingga segala pengetahuan tentang inventaris sulit disebarkan dan dimanfaatkan. Selain itu sistem inventaris belum ada fasilitas khusus yang memudahkan pegawai dalam berkomunikasi secara online.

\subsection{Analisis fungsional}

\section{Use Case Diagram}

Use case menceritakan tentang sebuah interaksi antara satu atau lebih aktor sitem yang akan dibuat.

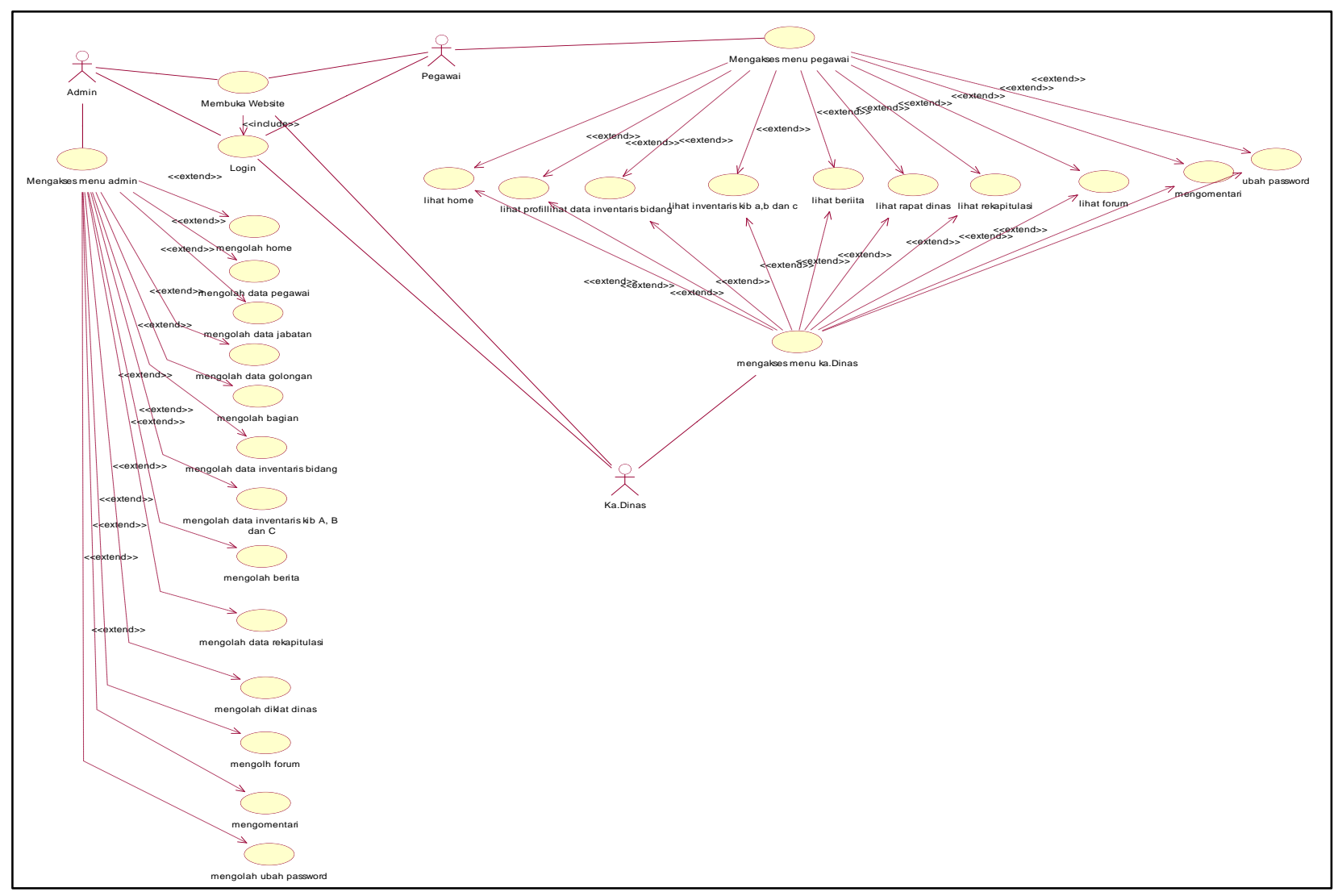

Gambar 4 Use case Diagram 


\section{Class Diagram}

Sebuah class diagrammenjelaskan tipe dari objek dalam sebuah sistem dan berbagai hubungan yang terdapat diantara objek-objek tersebut. Class Diagram dapat dilihat pada gambar 5 .

\subsection{Analisis Interaksi}

Analisis Interaksi dapat digambarkan melalui activity diagram menggambarkan workflow (aliran kerja) atau aktivitas dari sebuah sistem atau proses bisnis. Activity Diagram dapat dilihat pada gambar 6,7, dan 8 .

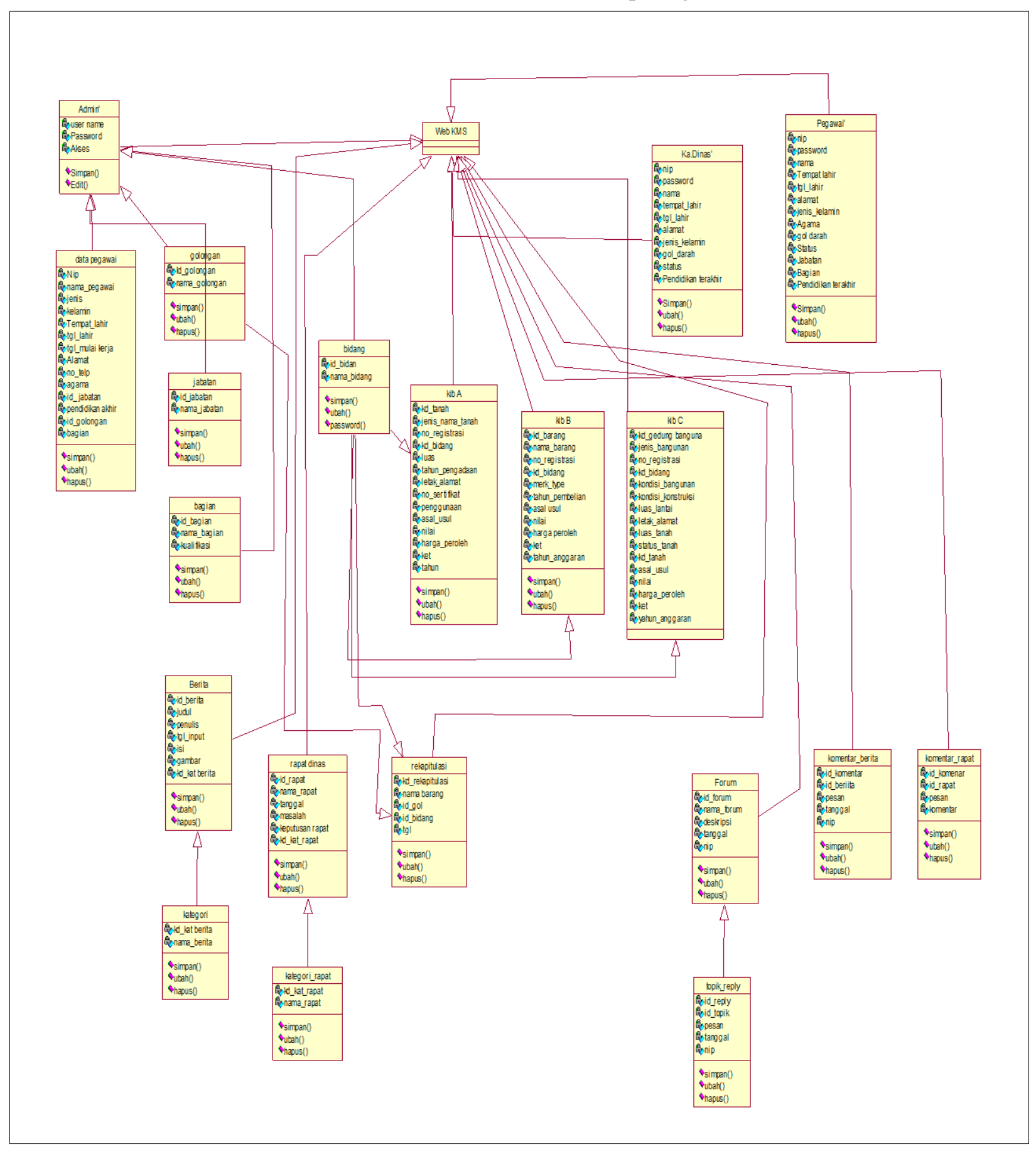

Gambar 5 Class Diagram 


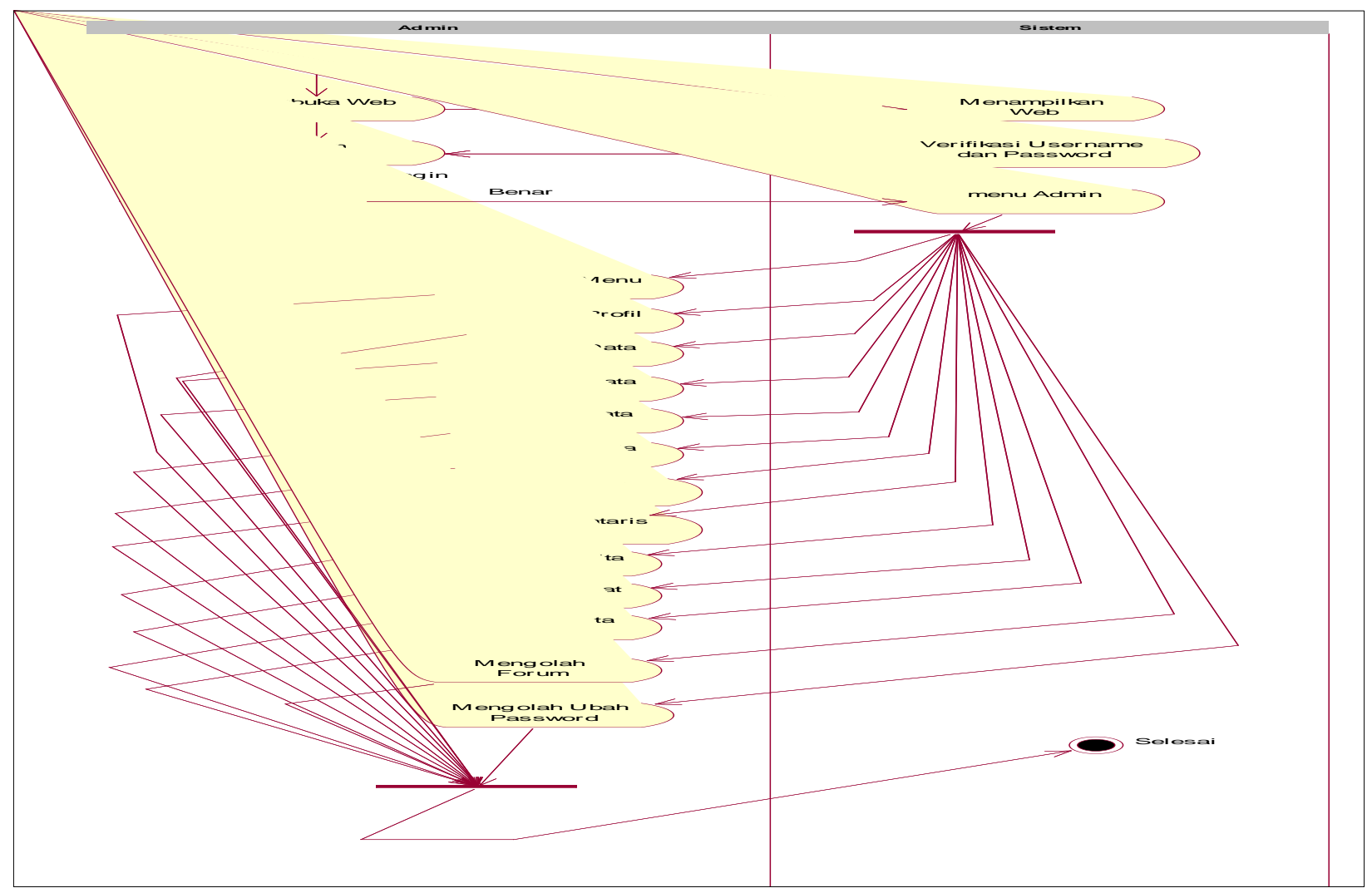

Gambar 6. Activity Diagram Admin

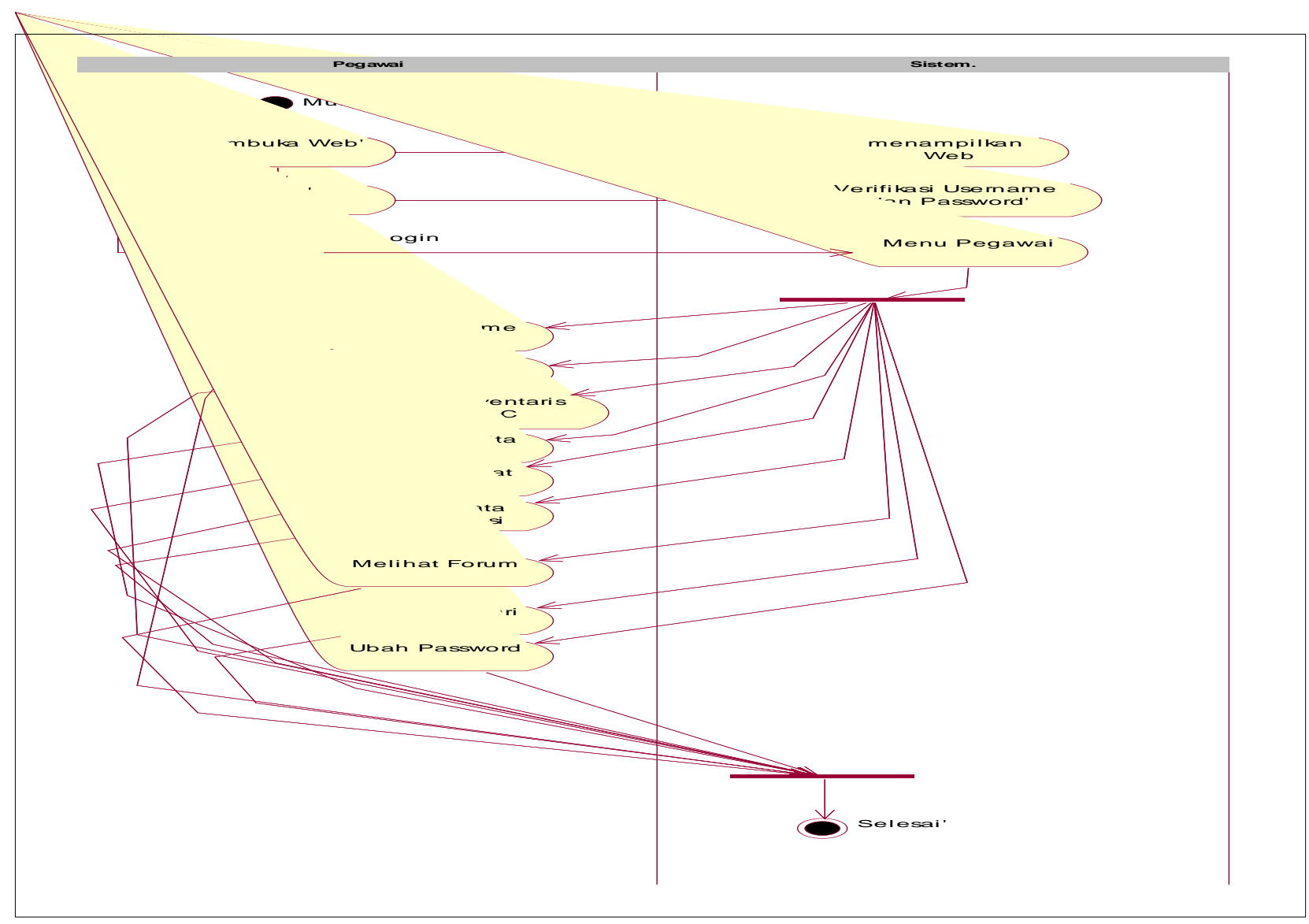

Gambar 7. Activity Diagram Pegawai 


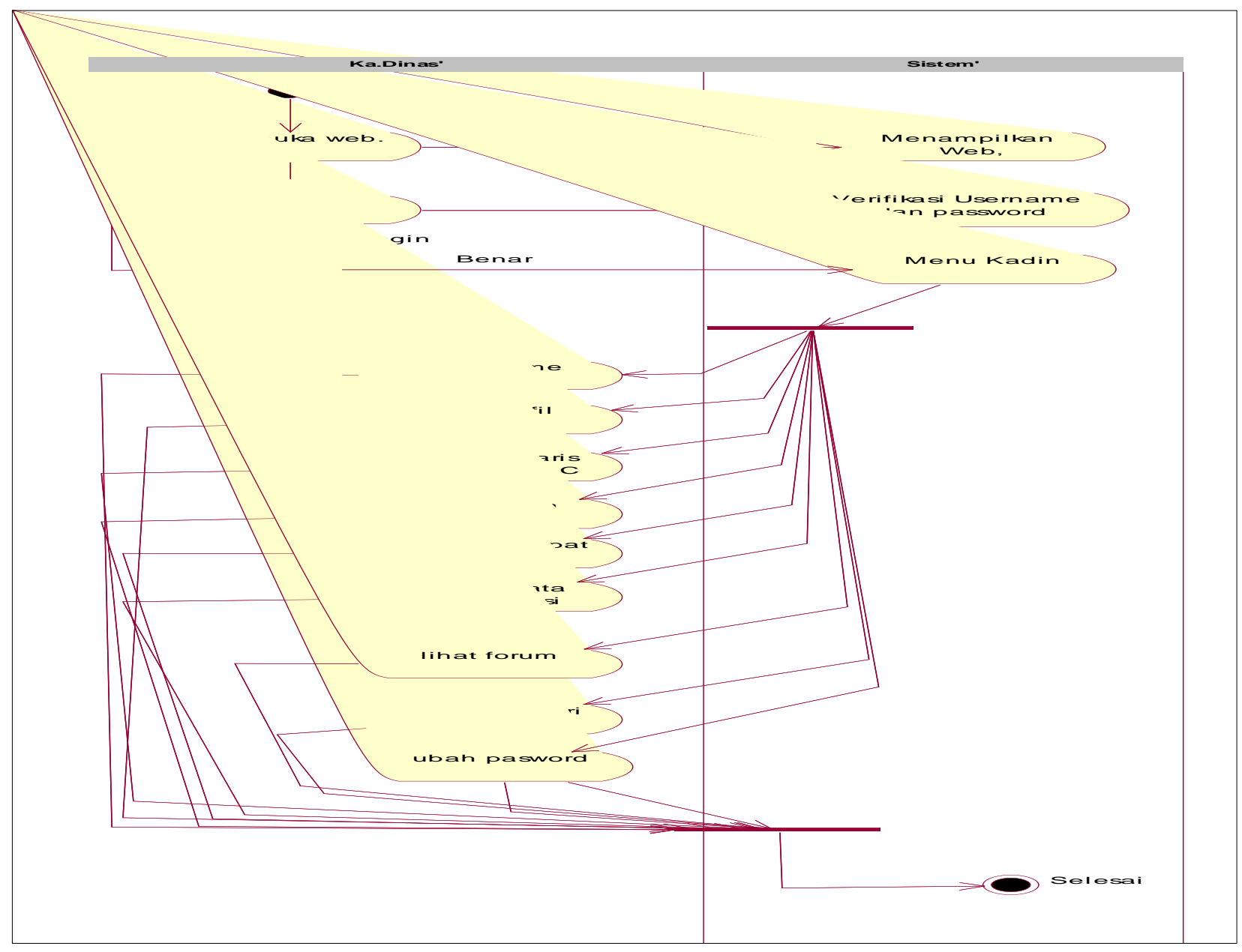

Gambar 8. Activity Diagram Ka.Dinas

\subsection{Prototyping Website Knowlwdge \\ Management System}

Prototype aplikasi perangkat lunak ini akan menjelaskan tampilan aplikasi yang berkaitan dengan penggunaannya. Dari penelitian yang telah dilakukan, menghasilkan suatu prototype knowledge management system pada Kantor Dinas Ogan Ilir.

\section{Halaman Menu Login User}

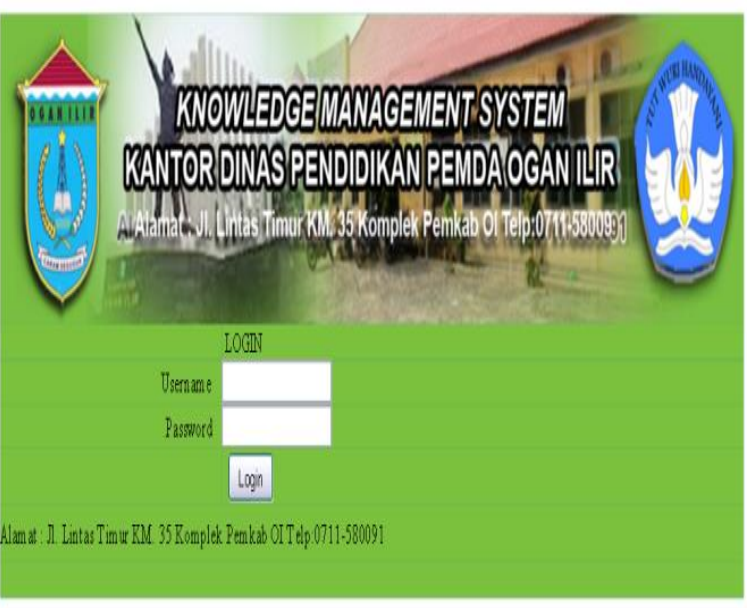

Halaman Utama adalah halaman yang menampilkan menu-menu yang ada di sebuah system. Tampilan halaman utama dapat dilihat pada gambar 9.

\section{Gambar 9. Halaman Login}

\section{Halaman Utama Admin}

Halaman Utama admin adalah halaman yang akan menampilkan menu-menu dan 
informasi berita. Tampilan halaman home admin dapat dilihat pada gambar 10 .

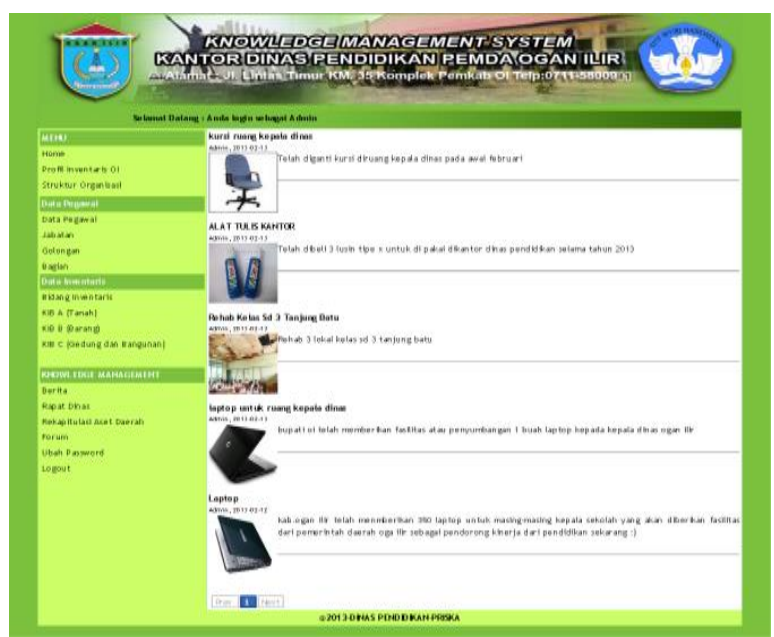

Gambar 10. Halaman Home Admin

\section{Halaman Utama Ka.Dinas}

Halaman home ka.dinas adalah halaman yang akan menampilkan menu-menu dan informasi berita. Tampilan halaman home ka.dinas dapat dilihat pada gambar 11 .

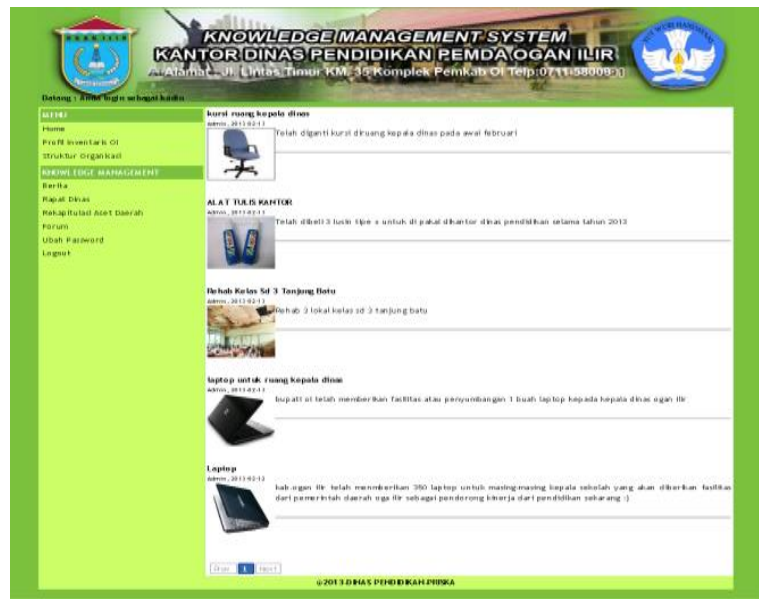

Gambar 11. Halaman Home Ka.Dinas

\section{Halaman Home Staff}

Halaman home Staff adalah halaman yang akan menampilkan menu-menu staf dan informasi berita. Tampilan halaman home Staff dapat dilihat pada gambar 12 .

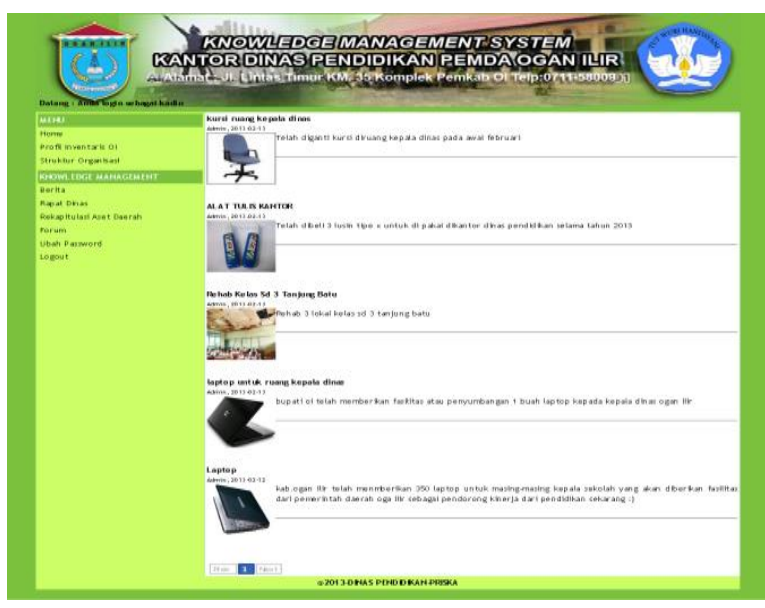

\section{Gambar 12. Halaman Home Staff}

5. Halaman Lihat Rekapitulasi Inventaris

Halaman lihat rekapitulasi inventaris adalah halaman yang akan menampilkan tentang laporan inventaris barang kantor dinas pendidikan. Tampilan halaman rekapitulasi inventaris dapat dilihat pada gambar 13.

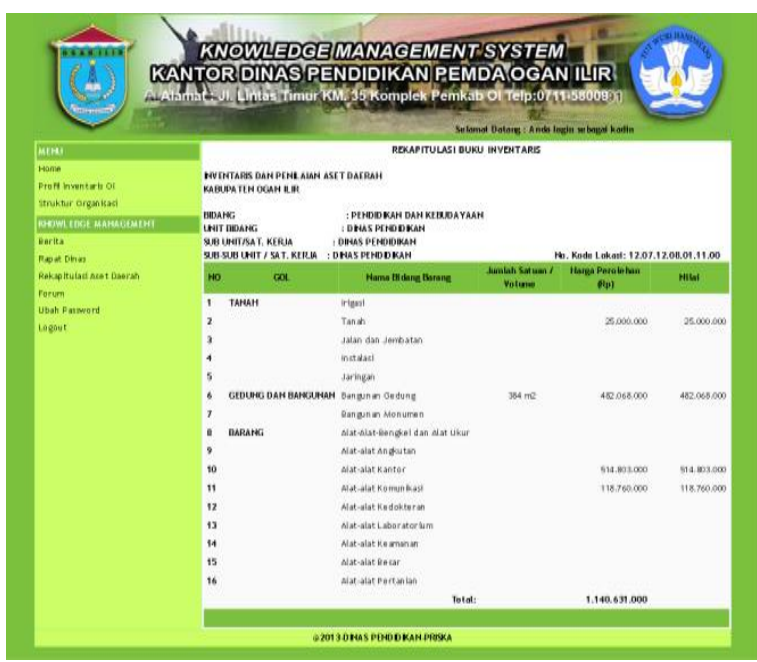

Gambar 13. Halaman Lihat Rekapitulasi

\section{Halaman Forum Diskusi}

Halaman Forum Diskusi adalah halaman yang akan menampilkan tentang diskusi topik yang di bicarakan semua pegawai yang ada pada kantor dinas pendidikan. Tampilan halaman Forum diskusi dapat dilihat pada gambar 14. 


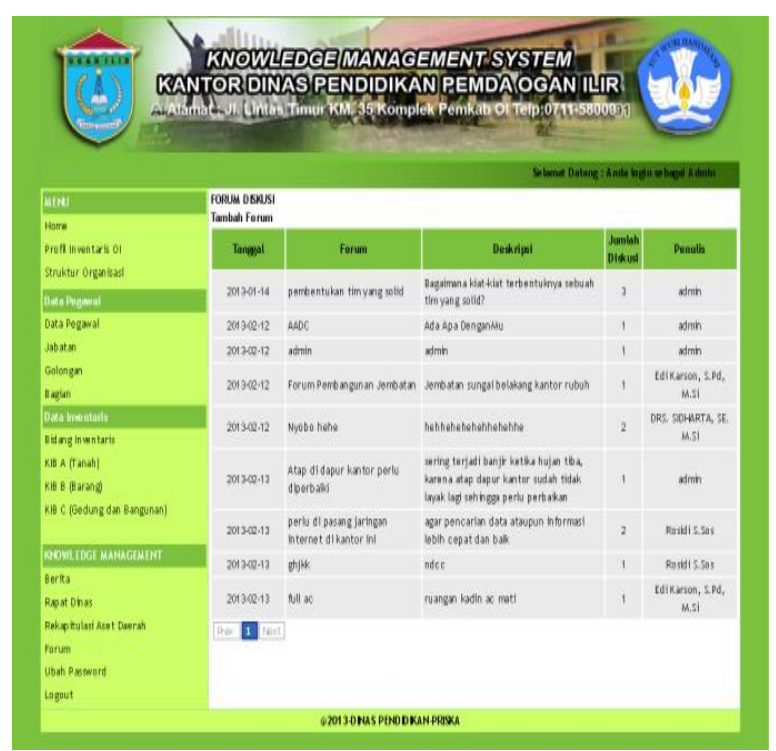

Gambar 14. Halaman Forum Diskusi

\section{Halaman Lihat Rapat Dinas}

Halaman lihat Rapat Dinas adalah halaman yang akan menampilkan tentang hasil keputusan rapat. Tampilan halaman lihat rapat dinas dapat dilihat pada gambar 15 .

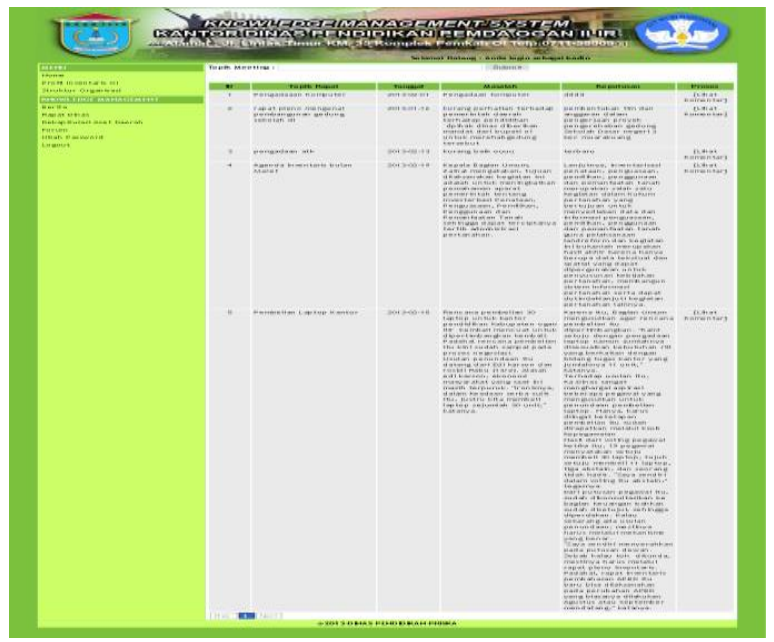

\section{Gambar 15. Halaman Lihat Rapat Dinas}

\section{Halaman Komentar Rapat}

Halaman input lihat dan komentar rapat adalah halaman yang akan menampilkan tentang hasil keputusan rapat yang akan dikomentari. Tampilan halaman lihat rapat dinas dapat dilihat pada gambar 16.

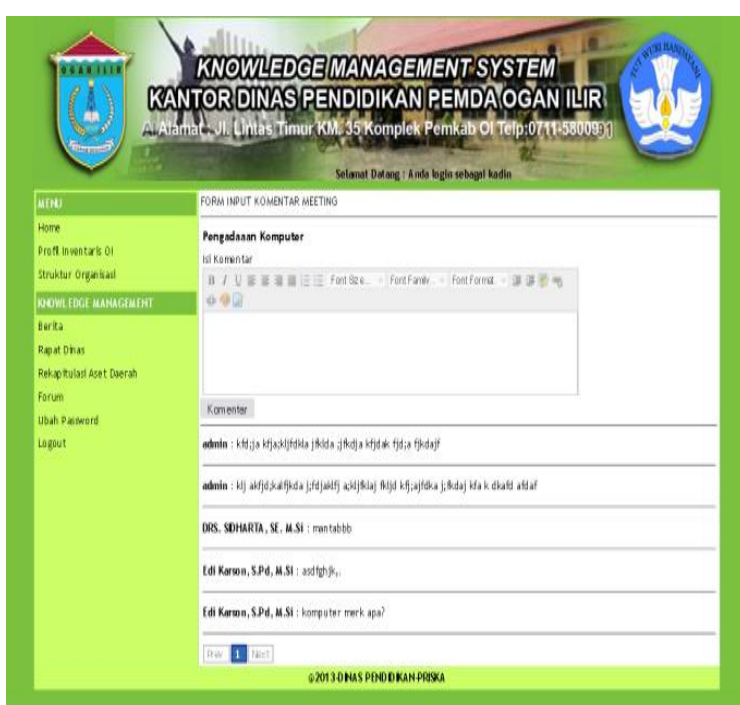

Gambar 16. Halaman Komentar Rafat

\section{SIMPULAN}

Dari hasil uraian diatas, yang berupa analisis dan pemecahan masalah, maka dapat ditarik kesimpulan yang diharapkan dapat bermanfaat bagi Kantor Dinas Pendidikan PEMDA Ogan Ilir yaitu bahwa; Permasalahan Kantor Dinas Pendidikan PEMDA Ogan Ilir, belum mempunyai Kowledge Management System Berbasis Web. Selain itu Sistem baru yang akan dibentuk yaitu perancangan knowledge management system pada kantor dinas pendidikan PEMDA Ogan Ilir dengan menghasilkan Prototype. Dalam Perancangan Knowledge Management System ini menghasilkan beberapa menu yaitu berita, rapat dinas, rekapitulasi aset inventaris, forum diskusi aplikasi knowledge berbasis web. 


\section{DAFTAR RUJUKAN}

Basit, D. A. Model prototype. (Online).

(Diakses

dari

http://denysilvanes.wordpress.com/2

010/03/26/model-prototype/, $\quad 14$

Desember 2010)

Nawawi, I.dkk 2012. Knowledge

Management (Teori dan aplikasi dalam mewujudkan daya saing organisasi bisnis dan publik). Bogor:

Ghalia Indonesia

Tobing, P. L. (2007). Knowledge Management: Konsep, Arsitektur dan Implementasi. Yogyakarta: Graha Ilmu.

Yakub. 2012. Pengantar Sistem Informasi. Yogyakarta: Graha Ilmu.

Sutabri, Tata. 2012. Konsep Sistem Informasi. Yogyakarta: Andi.

Simarmata, J. 2006. Aplikasi mobile commerce menggunakan PHP dan $M y S Q L$. Andi. Yogyakarta.

Pressman, R. S. 2002. Rekayasa perangkat lunak : Pendekatan praktisi (buku satu), Terj. Software Engineering : A practitioner's approach, L. N. Harnaningrum (Pen.). Andi. Yogyakarta.

Sukarno, M. 2006. Membangun website dinamis interaktif dengan PHPMySQL (windows \& linux). Eska Media. Jakarta. 